\title{
PENGARUH KOMPETENSI PEDAGOGIK DAN KESIAPAN GURU TERHADAP IMPLEMENTASI KURIKULUM 2013
}

\author{
Roni Alim Ba'diya Kusufa \\ Universitas Kanjuruhan Malang \\ roniabk@unikama.ac.id
}

\begin{abstract}
Abstrak
Kurikulum merupakan salah satu hal penting dalam sistem pendidikan Indonesia. Permasalahan pendidikan yang dihadapi sekarang membuat Kemendikbud menilai bahwa perlu dikembangkannya kurikulum baru, yaitu Kurikulum 2013. Kompetensi pedagogik merupakan kemampuan guru mengelola pembelajaran yang terdiri dari pemahaman terhadap siswa, perencanaan, implementasi pembelajaran, evaluasi hasil belajar dan mengaktualisasikan segenap potensi siswa. Kesiapan guru merupakan kesiapan sebagai agen pembelajaran yang berfungsi untuk meningkatkan mutu pendidikan nasional dimana guru berperan mentransfer ilmu pengetahuan ke peserta didik. Untuk mengetahui faktor penentu keberhasilan Kurikulum 2013 khususnya kesiapan guru dalam mengimplementasikan kurikulum 2013 maka perlu dilaksanakan penelitian. Tujuan penelitian ini mengacu pada permasalahan yaitu untuk mengetahui pengaruh kompetensi pedagogik dan kesiapan guru secara sendiri-sendiri maupun secara bersama-sama terhadap implementasi kurikulum 2013. Penelitian ini menggunakan pendekatan kuantitatif dengan desain ex post facto. Penelitian ini mencari data empirik yang sistematik dan dalam penelitian ini peneliti tidak dapat mengontrol langsung variabel bebas karena peristiwanya telah terjadi dan menurut sifatnya tidak dapat dimanipulasi. Populasi dalam penelitian ini adalah seluruh guru yang berjumlah 51 guru. Teknik pengumpulan data menggunakan angket, wawancara dan dokumentasi. Teknik analisis data menggunakan deskriptif, uji prasyarat dan pengujian hipotesis. Hasil penelitian, maka dapat ditarik kesimpulan sebagai berikut: (1). Kompetensi pedagogik berpengaruh terhadap implementasi kurikulum 2013. (2). Kesiapan guru berpengaruh terhadap implementasi kurikulum 2013. (3). Kompetensi pedagogik dan kesiapan guru berpengaruh terhadap implementasi kurikulum 2013.
\end{abstract}

Kata Kunci: Kompetensi pedagogik, kesiapan guru, Kurikulum 2013

\section{PENDAHULUAN}

Semakin majunya era teknologi informasi dan komunikasi, semakin berkembang pula dunia pendidikan. Di suatu negara, pendidikan sangat berpengaruh terhadap kehidupan berbangsa dan bernegaranya. Demikian halnya dengan Indonesia, yang menaruh harapan besar terhadap pendidik dalam perkembangan masa depan bangsa ini, karena dari sanalah tunas muda harapan bangsa sebagai generasi penerus dibentuk. Harus diakui bahwa pendidikan di Indonesia masih belum selesai dengan problematika sarana dan prasarana, dan sekarang karakter bangsa pun juga harus diperbaiki.
Kurikulum merupakan salah satu hal penting dalam sistem pendidikan Indonesia. Tujuan disusunnya kurikulum adalah untuk mewujudkan tujuan pendidikan nasional dengan memperhatikan perkembangan peserta didik, kebutuhan pembangunan nasional, serta perkembangan ilmu pengetahuan, teknologi informasi dan seni budaya. Permasalahan pendidikan yang dihadapi sekarang membuat Kemendikbud menilai bahwa perlu dikembangkannya kurikulum baru, yaitu Kurikulum 2013 (Kemendikbud 2013a). Hasil analisis PISA menunjukkan hampir seluruh siswa Indonesia hanya menguasai pelajaran 
sampai level 3 saja, sementara negara lain banyak yang sampai level 4, 5 bahkan 6 (Kemendikbud 2013b). Kurikulum 2013 merupakan revisi dan tindak lanjut dari Kurikulum Berbasis Kompetensi (KBK) yang pernah diujicobakan pada tahun 2004. Kurikulum Berbasis Kompetensi (KBK) dijadikan sebagai pedoman dan acuan bagi pelaksanaan pendidikan guna mengembangkan berbagai ranah pendidikan (pengetahuan, ketrampilan, dan sikap) dalam seluruh jenjang dan jalur pendidikan di Indonesia, khususnya pada jalur pendidikan sekolah/formal.

Kurikulum 2013 menuntut guru untuk melaksanakan kegiatan pembelajaran yang berbasis tematik integratif dan pendekatan sains. Namun Kurikulum 2013 akan sulit dilaksanakan di berbagai daerah sebagian besar dikarenakan ketidaksiapan guru. Oleh karena itu, guru diharapkan lebih kreatif dalam melaksanakan kegiatan pembelajaran, agar mereka mampu menjadi fasilitator, dan mitra belajar bagi peserta didik.

Berbagai pendapat yang berkembang dengan adanya perubahan kurikulum menunjukkan bahwa guru memegang peran penting dalam perubahan kurikulum. Sebaik apapun kurikulum yang dibuat, jika guru yang menjalankan tidak memiliki kemampuan yang baik, maka kurikulum tersebut tidak akan berjalan dengan baik. Yusuf (2007) menyatakan dalam implementasi KTSP, kesiapan sekolah mencakup kesiapan materiil dan non materiil. Kesiapan tersebut meliputi kesiapan perangkat kurikulum, sarana prasarana sekolah, kesiapan anggaran pendidikan, dan terakhir kesiapan guru. Hal tersebut sedikit berbeda dengan kesiapan dalam implementasi kurikulum 2013 yang tidak berdasarkan tingkat satuan pendidikan. Sikdisnas (2012) menyatakan sedikitnya ada dua faktor besar dalam keberhasilan kurikulum 2013. Faktor penentu pertama yaitu kesesuaian kompetensi pendidik dan tenaga kependidikan dengan kurikulum dan buku teks. Faktor penentu kedua yaitu faktor pendukung yang terdiri dari tiga unsur, yaitu: (i) ketersediaan buku sebagai bahan ajar dan sumber belajar yang mengintegrasikan standar pembentuk kurikulum; (ii) penguatan peran pemerintah dalam pembinaan dan pengawasan; dan (iii) penguatan manajemen dan budaya sekolah.

Kurikulum baru menuntut guru untuk melaksanakan pembelajaran yang berbasis tematik integratif. Guru juga dituntut untuk tidak hanya memiliki kompetensi profesional, namun juga harus memiliki kompetensi pedagogik, sosial, dan kepribadian. Kurikulum 2013 juga menuntut guru untuk melakukan pembelajaran berbasis pendekatan sains. Kompetensi pedagogik guru perlu untuk diketahui karena kompetensi tersebut berkaitan dengan pengembangan kurikulum serta proses pembelajaran yang dilakukan di dalam kelas. Selain itu, dalam kompetensi pedagogik, guru dituntut untuk memahami karateristik peserta didik, sehingga guru dapat menerapkan pendidikan karakter secara spontan dalam setiap proses pembelajaran agar siswa dapat memenuhi kompetensi sikap. Setelah diketahui mengenai kompetensi pedagogik guru, diharapkan dapat menjadi acuan untuk penelitian lanjutan mengenai kompetensi lain yaitu kepribadian, sosial, dan profesional.

Untuk mengetahui faktor penentu keberhasilan Kurikulum 2013 khususnya kesiapan guru dalam 
mengimplementasikan kurikulum 2013 maka perlu dilaksanakan penelitian pengaruh kompetensi pedagogik dan kesiapan guru terhadap implementasi kurikulum 2013, dimana penelitian ini dilaksanakan di MTs Nurul Ulum Malang.

Tujuan penelitian ini mengacu pada permasalahan yang telah disebutkan di atas yaitu untuk mengetahui pengaruh kompetensi pedagogik dan kesiapan guru secara sendiri-sendiri maupun secara bersama-sama terhadap implementasi kurikulum 2013.

\section{METODE PENELITIAN}

Sesuai dengan judul "Pengaruh kompetensi pedagogik dan kesiapan guru terhadap implementasi kurikulum 2013", maka variabel penelitiannya terdiri dari:

1. Variabel bebas (independent)

a. Kompetensi Pedagogik sebagai

$\mathrm{X} 1$

b. Kesiapan Guru sebagai $\mathrm{X}_{2}$

2. Variabel terikat (dependent)

Dalam penelitian ini yang menjadi variabel terikat adalah "implementasi kurikulum 2013" yang disimbolkan dengan huruf "Y".

Pendekatan ini menggunakan pendekatan kuantitatif dengan desain ex post facto. Populasi dalam penelitian ini adalah seluruh guru MTs Nurul Ulum Malang. Berdasarkan data yang diperoleh jumlah Populasi dalam penelitian ini adalah seluruh guru di MTs Nurul Ulum Malang yang berjumlah 51 guru. Karena jumlah guru kurang dari 100 maka teknik pengambilan sampel menggunakan sampel jenuh dimana seluruh populasi diambil sampel, jadi dalam penelitian ini jumlah sampelnya seluruh guru di MTs Nurul Ulum Malang yaitu 51 guru.
Instrumen yang digunakan untuk mengungkap data dalam penelitian ini adalah angket atau kuesioner tertutup. Dalam penelitian kuantitatif, data dalam penelitian ini harus diubah menjadi angka-angka yaitu dengan penskoran. Dengan skala Likert, maka variabel yang diukur dijabarkan menjadi indikator, kemudian indikator tersebut dijadikan sebagai titik tolok ukur untuk menyusun item-item instrumen yang dapat berupa pernyataan atau pertanyaan. Jawaban setiap instrumen yang menggunakan skala Likert mempunyai gradasi dari yang sangat positif sampai sangat negatif dapat berupa kata-kata antara lain: Sangat Setuju, Setuju, Tidak Setuju dan Sangat Tidak Setuju. Selain itu dapat juga menggunakan kata-kata Selalu, Sering, Jarang dan Tidak Pernah.

Uji coba instrumen dilakukan dengan menggunakan teknik One-Shoot atau pengukuran sekali saja. Teknik Oneshoot adalah teknik uji coba instrumen penelitian dengan penyebaran kuesioner satu kali saja.

Analisis data menggunakan analisis deskriptif bertujuan untuk mendeskripsikan atau menjelaskan tentang gambaran yang diteliti berdasarkan data dari variabel yang diperoleh, dan tidak dimaksudkan untuk pengujian hipotesis. Penyajian hasil analisis deskriptif biasanya berupa frekuensi dan persentase, tabulasi silang, berbagai bentuk grafik dan chart pada data yang bersifat kategorikal, serta berupa statistikstatistik kelompok seperti nilai rata-rata (mean). (Saifuddin Azwar, 2012: 126).

2. Uji Prasyarat Analisis
a. Uji Normalitas
b. Uji Linearitas
c. Uji Multikolinearitas
d. Uji Homokedastisitas 
3. Pengujian Hipotesis
a. Menguji Signifikansi Prediktor secara Parsial dengan Uji t
b.Menguji Signifikansi Seluruh Prediktor secara Bersama-Sama dengan Uji F
c. Mencari Besarnya Nilai Koefisien Determinasi (R2)
d. Mencari Sumbangan dari Variabel Bebas terhadap Variabel Terikat
1) Sumbangan Relatif (SR)
2) Sumbangan Efektif (SE)

\section{HASIL DAN PEMBAHASAN}

\section{Deskripsi Data Penelitian}

Deskripsi hasil penelitian yang diperoleh dari pengumpulan data dengan instrumen penelitian skala likert. Pemaparan tersebut meliputi variabel-variabel: pengaruh kompetensi pedagogik dan kesiapan guru terhadap implementasi kurikulum 2013 yang mencakup mean, median, standart deviation, variance, skor minimum, dan skor maksimum. Jika Y menyatakan variabel terikat (implementasi kurikulum 2013) maka X menyatakan variabel bebas yang terdiri atas $\mathrm{X}_{1}$ (kompetensi pedagogik), dan $\mathrm{X}_{2}$ (kesiapan guru), maka rangkuman peroleh skor data variabel penelitian disajikan sebagai berikut:

\section{Tabel 1. Skor Data Empirik Variabel} Penelitian

\begin{tabular}{|l|l|l|l|}
\hline & Mean & $\begin{array}{l}\text { Std. } \\
\text { Deviati } \\
\text { on }\end{array}$ & $\mathrm{N}$ \\
\hline $\begin{array}{l}\text { Y: Implementasi } \\
\text { kurikulum 2013 }\end{array}$ & 64,18 & 7,999 & 51 \\
$\begin{array}{l}\text { X1: Kompetensi } \\
\text { Pedagogik } \\
\text { X2: Kesiapan } \\
\text { Guru }\end{array}$ & 59,76 & 7,157 & 51 \\
\hline
\end{tabular}

Sumber: Data diolah peneliti (2016)
Berdasarkan tabel 4.1, diketahui bahwa jumlah data yang valid (sah untuk diproses pada kompetensi pedagogik $\left(\mathrm{X}_{1}\right)$ adalah 20 data dengan jumlah responden 51 guru, sedangkan data yang hilang (missing) adalah nol, berarti semua data siap diproses. Mean atau rata-rata pada kompetensi pedagogik $\left(\mathrm{X}_{1}\right)$ dari 51 responden adalah sebesar 59,76 dengan standar deviasi (besar tingkat kesalahan atau eror) data sebesar 7,157 , artinya data yang digunakan cukup baik.

Variabel kesiapan guru $\left(\mathrm{X}_{2}\right)$, diketahui bahwa jumlah data yang valid adalah 25 pernyataan, sedangkan data yang hilang (missing) adalah nol, berarti semua data siap diproses. Mean (rata-rata) pada kesiapan guru $\left(\mathrm{X}_{2}\right)$ dari 51 responden adalah sebesar 71,39 dengan standar deviasi (besar tingkat kesalahan atau eror) data sebesar 9,556, artinya data yang digunakan cukup baik

Variabel implementasi kurikulum 2013 (Y), diketahui bahwa jumlah data yang valid adalah 20 pertanyaan, sedangkan data yang hilang (missing) adalah nol, berarti semua data siap diproses. Mean (rata-rata) pada implementasi kurikulum 2013 (Y) dari 51 responden adalah sebesar 64,18 dengan standar deviasi (besar tingkat kesalahan atau eror) data sebesar 7,999, artinya data yang digunakan cukup baik. Berdasarkan deskripsi di atas, dapat diambil kesimpulan bahwa data variabel penelitian yaitu kompetensi pedagogik $\left(\mathrm{X}_{1}\right)$, kesiapan guru $\left(\mathrm{X}_{2}\right)$, terhadap implementasi kurikulum 2013 (Y) dapat diproses dan dianalisa, dikarenakan data yang tersedia valid dan tidak terdapat data yang hilang (missing).

\section{Uji Asumsi Klasik}

Model regresi mengasumsikan tidak adanya multikolinieritas atau tidak 
adanya hubungan (korelasi) yang sempurna antara variabel bebas yang satu dengan variabel bebas yang lain. Salah satu cara yang umum digunakan untuk mendeteksi adanya multikolinieritas dengan cara melihat nilai Variance Inflation Factor (VIF) masing- masing variabel bebas, dimana jika nilai terdapat VIF $>5$, maka terdapat gejala multikolinieritas dalam model regresi.

Model regresi linier mengasumsikan bahwa varian residual bersifat konstan atau sama untuk berbagai pengamatan atau tidak adanya model heteroskedastisitas dalam model regresi. Pengujian gejala heteroskedastisitas dapat dilakukan dengan menggunakan grafik scatterplot. Kriteria pengujian heteroskedastisitas dengan model grafik, apabila penyebaran data tidak membentuk pola tertentu (acak), berarti data homoskedastis atau tidak terdapat heteroskedastisitas.

Uji autokorelasi sering dikenal dengan korelasi serial dan sering ditemukan pada data serial waktu. Regresi yang terdeteksi autokorelasi dapat berakibat pada biasnya interval kepercayaan dan ketidaktepatan penerapan uji $\mathrm{t}$ dan uji $\mathrm{F}$. Model regresi yang baik jika semua variabel berdistribusi normal. Apabila data menyebar di sekitar garis diagonal dan arah penyebaran mengikuti arah garis diagonal maka data didistribusikan normal.

Tabel 2. Ikhtisar Uji Asumsi Klasik

\begin{tabular}{|c|c|c|c|c|}
\hline $\begin{array}{l}N \\
\mathrm{O}\end{array}$ & $\begin{array}{l}\text { Uji } \\
\text { Asumsi } \\
\text { Klasik }\end{array}$ & Syarat & $\begin{array}{l}\text { Hasil Uji } \\
\text { Asumsi } \\
\text { Klasik }\end{array}$ & Ketera-ngan \\
\hline 1 & $\begin{array}{l}\text { Uji } \\
\text { Multikol } \\
\text { i-nieritas }\end{array}$ & $\mathrm{VIF}<5$ & $\begin{array}{l}\mathrm{X} 1: \\
\mathrm{VIF}=1.3 \\
99 \\
\mathrm{X} 2: \\
\mathrm{VIF}=1.3 \\
99\end{array}$ & $\begin{array}{l}\text { Tidak } \\
\text { terjadi } \\
\text { multikolinie } \\
\text { ritas }\end{array}$ \\
\hline
\end{tabular}

\begin{tabular}{|c|c|c|c|c|}
\hline 2 & $\begin{array}{l}\text { Uji } \\
\text { Heterosk } \\
\text { e- } \\
\text { dastisitas }\end{array}$ & $\begin{array}{l}\text { Data } \\
\text { tersebar } \\
\text { secara } \\
\text { acak dan } \\
\text { tidak } \\
\text { mem } \\
\text { bentuk } \\
\text { suatu } \\
\text { pola }\end{array}$ & $\begin{array}{l}\text { Titik } \\
\text { menyeba } \\
\text { r secara } \\
\text { acak dan } \\
\text { tidak } \\
\text { mem } \\
\text { bentuk } \\
\text { suatu } \\
\text { pola }\end{array}$ & $\begin{array}{l}\text { Tidak } \\
\text { terjadi } \\
\text { heteroskeda } \\
\text { stisitas }\end{array}$ \\
\hline 3 & $\begin{array}{l}\text { Uji } \\
\text { Autokor } \\
\text { elasi }\end{array}$ & $\begin{array}{l}\text { Nilai D- } \\
\text { W } \\
\text { diantara } \\
-2 \\
\text { sampai } \\
+2, \\
\text { maka } \\
\text { tidak ada } \\
\text { korelasi }\end{array}$ & $\begin{array}{l}\text { D-W = } \\
1.957\end{array}$ & $\begin{array}{l}\text { Tidak } \\
\text { terjadi } \\
\text { autokorelasi }\end{array}$ \\
\hline 4 & $\begin{array}{l}\text { Uji } \\
\text { Normalit } \\
\text { as }\end{array}$ & $\begin{array}{l}\text { Data } \\
\text { menyeba } \\
\text { r di } \\
\text { sekitar } \\
\text { garis } \\
\text { diagonal } \\
\text { dan arah } \\
\text { penyeba- } \\
\text { ran } \\
\text { mengiku } \\
\text { ti garis } \\
\text { diagonal }\end{array}$ & $\begin{array}{l}\text { Data } \\
\text { menyeba } \\
\text { r di } \\
\text { sekitar } \\
\text { garis } \\
\text { diagonal } \\
\text { dan arah } \\
\text { penyeba- } \\
\text { ran } \\
\text { mengiku } \\
\text { ti garis } \\
\text { diagonal }\end{array}$ & $\begin{array}{l}\text { Data } \\
\text { berdistri- } \\
\text { busi normal }\end{array}$ \\
\hline
\end{tabular}

Sumber: Data diolah peneliti (2016)

\section{Analisis Regresi Linier Berganda}

Uji regresi linear berganda digunakan untuk mengetahui besarnya pengaruh antar variabel bebas terhadap variabel terikat dalam bentuk persamaan regresi linear berganda. Hasil pengujian regresi linier berganda dapat dilihat sebagai berikut:

$$
\begin{aligned}
& Y=a+b_{1} X_{1}+b_{2} X_{2}+e \\
& Y=49,288+0,580+0,277+e
\end{aligned}
$$

Penjelasan dari persamaan regresi linier berganda tersebut sebagai berikut:

1) Konstanta sebesar 49,288 menunjukkan besarnya variabel kompetensi pedagogik $\left(\mathrm{X}_{1}\right)$, dan kesiapan guru $\left(\mathrm{X}_{2}\right)$ sebesar 0 .

2) Koefisien regresi kompetensi pedagogik $\left(\mathrm{X}_{1}\right)$ sebesar 0,580 . Hal 
ini mengandung arti bahwa setiap satu satuan variabel kompetensi pedagogik akan berpengaruh terhadap implementasi kurikulum 2013 sebesar 0,580 (58\%) dengan asumsi bahwa variabel bebas yang lain dari model regresi adalah tetap.

3) Koefisien regresi kesiapan guru $\left(\mathrm{X}_{2}\right)$ sebesar 0,277. Hal ini mengandung arti bahwa setiap satu satuan variabel kesiapan guru akan berpengaruh terhadap implementasi kurikulum 2013 sebesar 0, 277 $(27,7 \%)$ dengan asumsi bahwa variabel bebas yang lain dari model regresi adalah tetap.

4) $e$ merupakan faktor lain dari luar rancangan penelitian, artinya bahwa faktor lain selain kompetensi pedagogik, kesiapan guru dan implementasi kurikulum 2013.

\section{Pengujian Hipotesis}

1.Pengujian Koefisien Regresi Secara Parsial (Uji t)

Berdasarkan hasil perhitungan statistik dengan bantuan SPSS versi 22.0 for windows, untuk mengetahui pengaruh secara parsial tiap variabel independen terhadap variabel dependen dapat dilihat pada tabel berikut.

Tabel 3.Hasil Uji t

\begin{tabular}{|c|c|c|c|c|c|c|}
\hline \multirow{2}{*}{\multicolumn{2}{|c|}{ Model }} & \multicolumn{2}{|c|}{$\begin{array}{l}\text { Unstand- } \\
\text { ardized } \\
\text { Coefficients }\end{array}$} & \multirow{2}{*}{$\begin{array}{c}\begin{array}{r}\text { Standard } \\
\text { koefisien }\end{array} \\
\text { Beta }\end{array}$} & \multirow[b]{2}{*}{$\mathrm{t}$} & \multirow[t]{2}{*}{ Sig. } \\
\hline & & B & $\begin{array}{l}\text { Std. } \\
\text { Erro } \\
r\end{array}$ & & & \\
\hline \multirow[t]{3}{*}{1} & $\begin{array}{c}\text { Const } \\
\text { an }\end{array}$ & 49,288 & $\begin{array}{c}9,45 \\
7\end{array}$ & & $\begin{array}{c}5,21 \\
2\end{array}$ & 0,000 \\
\hline & $\mathrm{X} 1$ & 0,580 & $\begin{array}{c}0,17 \\
1\end{array}$ & 0,519 & $\begin{array}{c}3,39 \\
2\end{array}$ & 0,001 \\
\hline & $\mathrm{X} 2$ & 0,277 & $\begin{array}{c}0,12 \\
8\end{array}$ & 0,331 & $\begin{array}{c}2,16 \\
4\end{array}$ & 0,035 \\
\hline
\end{tabular}

Sumber: Data diolah peneliti (2016)

Uji $t$ digunakan untuk pengujian pengaruh masing-masing variabel bebas, maka interpretasi dilakukan sendiri-sendiri yaitu untuk kompetensi pedagogik $\left(\mathrm{X}_{1}\right)$, dan kesiapan guru $\left(\mathrm{X}_{2}\right)$. Pengujian dilakukan dengan cara membandingkan nilai $t_{\text {hitung }}$ dengan nilai $t_{\text {tabel }}$ pada taraf $\alpha=0,05$ dan derajat bebas $(\mathrm{n}-\mathrm{k}-1)=79-2-1=76$, dimana diperoleh nilai $\mathrm{t}_{\text {tabel }}=1,66$.

a. Pengujian kompetensi pedagogik $\left(\mathrm{X}_{1}\right)$ terhadap implementasi kurikulum 2013

Berdasarkan hasil analisis diperoleh nilai $\mathrm{t}_{\text {hitung }}=3,392$, sedangkan $\mathrm{t}_{\text {tabel }}$ $=1,66$ atau $t_{\text {hitung }}>t_{\text {tabel }}$ dengan signifikansi 0,001 lebih kecil dari 0,05 maka Ho ditolak (Ha diterima), artinya kompetensi pedagogik $\left(\mathrm{X}_{1}\right)$ memiliki pengaruh yang signifikan terhadap implementasi kurikulum 2013.

b. Pengujian kesiapan guru $\left(\mathrm{X}_{2}\right)$ terhadap implementasi kurikulum 2013

Berdasarkan hasil analisis diperoleh nilai $\mathrm{t}_{\text {hitung }}=2,164$, sedangkan $\mathrm{t}_{\text {tabel }}$ $=1,66$ atau $t_{\text {hitung }}>t_{\text {tabel }}$ dengan signifikansi 0,035 lebih kecil dari 0,05 maka Ho ditolak (Ha diterima), artinya kesiapan guru $\left(\mathrm{X}_{2}\right)$ memiliki pengaruh yang signifikan terhadap implementasi kurikulum 2013

2. Pengujian Koefisien Regresi Secara Simultan (Uji F)

Uji $\mathrm{F}$ digunakan untk menguji hipotesis dari keseluruhan variabel yaitu: diduga bahwa variabel kompetensi pedagogik (X1), kesiapan guru (X2), secara simultan (bersama-sama) mempunyai pengaruh terhadap implementasi kurikulum 2013 (Y).

Berdasarkan hasil perhitungan statistik dengan bantuan SPSS versi 22.0 for windows, diperoleh tabel Anova yang menunjukkan hasil uji F. Adapun hasil 
uji $\mathrm{F}$ pada tabel Anova dapat dilihat pada tabel berikut.

Tabel 4. Anova

\begin{tabular}{|c|c|c|c|c|c|}
\hline Model & \begin{tabular}{|l|} 
Sum \\
of \\
Squar \\
es
\end{tabular} & df & $\begin{array}{l}\text { Mean } \\
\text { Squar } \\
\text { e }\end{array}$ & $\mathrm{F}$ & Sig. \\
\hline $\begin{array}{l}\text { Regressi } \\
\text { on }\end{array}$ & $\begin{array}{r}626,0 \\
53\end{array}$ & 2 & $\begin{array}{r}313,0 \\
27\end{array}$ & 5,839 & $\begin{array}{r}0,00 \\
5\end{array}$ \\
\hline Residual & $\begin{array}{r}2573, \\
358\end{array}$ & $\begin{array}{l}4 \\
8\end{array}$ & $\begin{array}{r}53,61 \\
2\end{array}$ & & \\
\hline Total & $\begin{array}{r}3199, \\
412\end{array}$ & $\begin{array}{l}5 \\
0\end{array}$ & & & \\
\hline
\end{tabular}

Sumber: Data diolah peneliti (2016)

Hasil Anova diperoleh nilai $F_{\text {hitung }}$ sebesar 5,839, selanjutnya untuk pengujian hipotesis, maka nilai tersebut dibandingkan dengan nilai $\mathrm{F}_{\text {tabel }}$ pada taraf $\alpha=0,05$ derajat bebas $=2: 51$ yaitu sebesar 2,75, maka $F_{\text {hitung }}(5,839)>$ $\mathrm{F}_{\text {tabel }}(2,75)$ atau nilai signifikan $0,005<$ 0,05, maka Ho ditolak (Ha diterima), artinya kompetensi pedagogik (X1), dan kesiapan guru (X2) secara simultan mempunyai pengaruh yang signifikan terhadap implementasi kurikulum 2013 (Y). Hal ini menunjukkan bahwa banyak faktor-faktor lain yang mempengaruhi implementasi kurikulum 2013 selain pembelajaran kompetensi pedagogik dan kesiapan guru.

\section{Pengaruh kompetensi pedagogik terhadap implementasi kurikulum 2013.}

Berdasarkan hasil analisis data yang dilakukan secara parsial, menunjukkan bahwa kompetensi pedagogik mempunyai pengaruh yang signifikan dan memberikan kontribusi sebesar $0,519(51,9 \%)$, terhadap implementasi kurikulum 2013. Disebutkan dalam landasan teori bahwa guru merupakan agen yang langsung terlibat dalam proses pembelajaran sehingga sosialisasi dalam perubahan kurikulum harus benar-benar menyentuh guru. Selain itu keberhasilan dari suatu kurikulum yang ingin dicapai sangat bergantung pada faktor kemampuan yang dimiliki oleh seorang guru (Uno, 2009). Guru bertugas untuk melaksanakan kurikulum dan bertanggung jawab untuk mengembangkan kurikulum.

Guru-guru MTs Nurul Ulum Malang telah menyampaikan materi sesuai dengan karakteristik siswa serta memastikan pemahaman siswa terhadap materi pelajaran. Kompetensi pedagogik mengenai pemahaman siswa perlu dikuasai guru karena berkaitan dengan struktur pengembangan Kurikulum 2013. Karakteristik Kurikulum 2013 mengembangkan keseimbangan antara pengembangan sikap spiritual dan sosial, rasa ingin tahu, kreativitas, kerjasama dengan kemampuan intelektual dan psikomotor (PP No. 69 Tahun 2013). Guru berusaha memahami karakter peserta didik dengan membedakan peserta didik menurut perbedaan kemampuan dan sikap, memberi tes awal pembelajaran dan memberi refleksi tiap akhir pembelajaran. Pemahaman mengenai kemampuan peserta didik membuat guru dapat mengidentifikasi peserta didik mana yang perlu mendapat perhatian lebih mengenai pembelajaran.

Berdasarkan Permendiknas nomor 16 tahun 2007 tentang standar kualitas akademik dan potensi guru, menyebutkan secara rinci kompetensi pedagogik. Guru-guru MTs Nurul Ulum Malang berusaha memahami karakteristik peserta didik dari aspek fisik, moral, spiritual, sosial, kultural emosional, dan intelektual. Pemahaman 
mengenai kemampuan peserta didik membuat guru dapat mengidentifikasi peserta didik mana yang perlu mendapat perhatian lebih mengenai pembelajaran.

Guru MTs Nurul Ulum Malang menguasai teori belajar dan prinsipprinsip pembelajaran yang mendidik, hal ini sesuai dengan tuntutan kurikulum 2013. Kurikulum 2013 menekankan bahwa guru mata pelajaran harus mengintegrasikan pelajaran TIK dalam setiap pembelajaran. Analisis hasil penelitian menunjukkan bahwa guru belum memanfaatkan teknologi informasi dan komunikasi dalam pembelajaran.

Guru MTs Nurul Ulum Malang belum memenuhi indikator kompetensi pedagogik mengenai memfasilitasi pengembangan potensi peserta didik dengan menyediakan kegiatan pembelajaran selain di ruang kelas. Selain itu, indikator kompetensi pedagogik yang penting yaitu kemampuan berkomunikasi. Kompetensi minimal seorang guru adalah menguasai ketrampilan mengajar dalam hal membuka dan menutup pelajaran, bertanya memberi penguatan, dan mengadakan variasi mengajar.

Kemendikbud (2013a) menyatakan penilaian Kurikulum 2013 dilakukan dengan memadukan tiga aspek pengetahuan (knowledge), kecakapan (skill), dan sikap (attitude). Guru dituntut untuk melakukan penilaian dan evaluasi proses dan hasil baik dari hasil tes kognitif, afektif maupun psikomotor. Selain itu, guru telah melakukan tindakan reflektif untuk peningkatan kualitas pembelajaran. Tindakan reflektif digunakan untuk mengetahui kekurangan atau permasalahan yang telah terjadi ketika proses pembelajaran. Setelah masalah dalam pembelajaran diketahui maka guru MTs Nurul Ulum Malang mencari solusi pemecahan masalah tersebut.

\section{Pengaruh kesiapan guru terhadap implementasi kurikulum 2013.}

Berdasarkan hasil analisa data yang dilakukan secara parsial menunjukkan bahwa kesiapan guru mempunyai pengaruh yang signifikan dan memberikan kontribusi sebesar 0,331 $(33,1 \%)$, terhadap implementasi kurikulum 2013. Guru MTs Nurul Ulum Malang memiliki pemahaman yang baik mengenai perubahan kurikulum 2013 dan memahami alasan pengembangan dari KTSP menjadi kurikulum 2013. Guru Mts Nurul Ulum Malang menilai bahwa salah satu kelemahan KTSP adalah membebani guru dengan administrasi yang banyak hingga kadang guru lebih mengutamakan administrasi daripada fokus mengajar. Kemendikbud (2013a) menyatakan pada Kurikulum 2013, penyusunan kurikulum dimulai dengan menetapkan standar kompetensi lulusan berdasarkan kesiapan peserta didik, tujuan pendidikan nasional dan kebutuhan. Diharapkan hal tersebut dapat merigankan tugas administrasi guru karena tidak harus dibebani dengan tugas-tugas penyusunan silabus yang memakan waktu dan memerlukan penguasaan teknis dalam penyusunan.

Guru MTs Nurul Ulum Malang merasa kurangnya aktualisasi informasi mengenai Kurikulum 2013, hal tersebut menghambat pelaksanaan implementasi kurikulum 2013 di sekolah. Menurut Husain et al (2011) yaitu guru harus memiliki pengetahuan tentang kurikulum dan memahami proses dimana kurikulum dapat dikembangkan. Dengan kurangnya aktualisasi informasi perkembangan kurikulum 2013 
menyebabkan kurangnya pengetahuan guru tentang kurikulum dan pemahaman pengembangan kurikulum.

Pengetahuan mengenai struktur dan pengembangan kurikulum 2013 guru MTs Nurul Ulum Malang cukup baik, guru memahami salah satu kriteria pendekatan ilmiah pada materi pembelajaran berbasis pada fakta dan fenomena yang dapat dijelaskan dengan logika atau penalaran tertentu, bukan sebatas kira-kira, khayalan, legenda, atau dongeng semata. Guru MTs Nurul Ulum Malang mendukung pemerintah dan siap untuk mengimplementasikan Kurikulum 2013. Guru selaku pelaksana kurikulum di lapangan tentu akan mendukung setiap kebijakan dari pemerintah dan dalam pelaksanaan kurikulum guru memegang peran penting. Hal ini sejalan dengan pendapat bahwa keberhasilan dari sutu kurikulum yang ingin dicapai sangat tergantung pada faktor kemampuan yang dimiliki oleh seorang guru (Uno,2009).

\section{Pengaruh kompetensi pedagogik dan kesiapan guru terhadap implementasi Kurikulum 2013.}

Berdasarkan hasil penelitian dan nilai $R$ Square, diketahui bahwa secara simultan antara kompetensi pedagogik dan kesiapan guru mempunyai pengaruh yang signifikan dan memberi kontribusi sebesar $0,196 \quad(19,6 \%) \quad$ terhadap implementasi kurikulum 2013. Hal ini berarti sisanya sekitar $0,804 \quad(80,4 \%)$ implementasi kurikulum 2013 dipengaruhi faktor-faktor lain selain kompetensi pedagogik dan kesiapan guru misalnya sarana prasarana sekolah, gaya kepemimpinan Kepala Sekolah dan lain-lain.
Kompetensi merupakan perbuatan yang bersifat profesional dan memenuhi spesifikasi di dalam melaksanakan tugas-tugas kependidikan. Menurut Mulyasa (2014) kompetensi guru merupakan perpaduan antara kemampuan personal, keilmuan, teknologi, sosial, dan spiritual yang secara kaffa membentuk kompetensi standar profesi guru, yang mencakup penguasaan materi, pemahaman terhadap peserta didik, pembelajaran yang mendidik, pengembangan pribadi dan profesionalisme. kompetensi guru merupakan kemampuan guru untuk mentransfer pengetahuan dan ketrampilannya dalam melaksanakan kewajiban pembelajaran secara profesional dan bertanggung jawab.

Guru MTs Nurul Ulum Malang telah memenuhi 8 (delapan) kualifikasi akademik dan potensi guru, diantara lain kompetensi pedagogik yang mencakup antara lain: (1) memahami karakteristik peserta didik dari aspek fisik, moral, spiritual, sosial, kultural emosional, dan intelektual. (2) Menguasai teori belajar dan prinsipprinsip pembelajaran yang mendidik. (3) Mengembangkan kurikulum yang terkait dengan mata pelajaran yang diampu. (4) Memfasilitasi pengembangan potensi peserta didik untuk mengaktualisasikan berbagai potensi yang dimiliki (5) Berkomunikasi secara efektif, empatik, dan santun dengan peserta didik (6) Menyelenggarakan penilaian dan evaluasi untuk kepentingan pembelajaran (7) Memanfaatkan hasil penilaian dan evaluasi untuk kepentingan pembelajaran, dan (8) Melakukan tindakan reflektif untuk peningkatan kualitas pembelajaran.

Guru MTs Nurul Ulum Malang belum memenuhi untuk 2 (dua) kualifikasi 
akademik dan potensi guru dalam kompetensi pedagogik, yaitu: (1) memanfaatkan teknologi informasi dan komunikasi untuk pembelajaran, dan (2) Memfasilitasi pengembangan potensi peserta didik untuk mengaktualisasikan berbagai potensi yang dimiliki. Hal ini dikarenakan keterbatasan siswa dalam menggunakan fasilitas dan sarana prasarana di sekolah seperti wifi. MTs Nurul Ulum di bawah naungan Yayasan Pendidikan Islam Ar-Rohmah, dimana sekolah berada di lingkungan pondok pesantren.

Kesiapan guru dalam mengimplementasikan kurikulum 2013 dikatakan baik, guru mampu mengaktualisasikan informasi perkembangan kurikulum 2013. Pada kurikulum 2013, penyusunan kurikulum dimulai dengan menetapkan standar kompetensi lulusan berdasarkan kesiapan peserta didik, tujuan pendidikan nasional dan kebutuhan. Setelah kompetensi ditetapkan kemudian ditentukan kurikulumnya yang terdiri dari kerangka dasar kurikulum dan struktur kurikulum. Satuan pendidikan dan guru tidak diberikan kewenangan menyusun silabus, tapi disusun pada tingkat nasional.

Kompetensi pedagogik guru MTs Nurul Ulum Malang yang baik dibarengi dengan kesiapan guru yang matang harusnya dapat mengimplementasikan kurikulum 2013 secara maksimal. Akan tetapi, guru MTs Nurul Ulum Malang belum dapat mengimplementasikan kurikulum 2013 secara maksimal dikarenakan kurangnya sarana teknologi informasi dan komunikasi. Peraturan pondok pesantren dalam pembatasan penggunaan teknologi dan komunikasi menyebabkan guru tidak secara maksimal mengembangkan potensi peserta didik untuk mengaktualisasikan berbagai potensi yang dimiliki. Penelitian ini sejalan dengan penelitian Evanita (2013), dimana penelitian ini juga menganalisis kompetensi pedagogik dan kesiapan guru Sekolah Menengah Atas dalam mendukung Implementasi Kurikulum 2013.

\section{KESIMPULAN \\ Kesimpulan}

Berdasarkan hasil penelitian, maka dapat ditarik kesimpulan sebagai berikut:

1. Kompetensi pedagogik berpengaruh terhadap implementasi kurikulum 2013.

2. Kesiapan guru berpengaruh terhadap implementasi kurikulum 2013.

3. Kompetensi pedagogik dan kesiapan guru berpengaruh terhadap implementasi kurikulum 2013.

\section{Saran}

Berdasarkan temuan dari penelitian ini, maka peneliti memberikan saran antara lain kepada:

1. Pemerintah

Pemerintah terutama Dinas

Pendidikan Kota Malang perlu memberikan sosialiasasi Kurikulum 2013 secara menyeluruh.

2. Kepala sekolah

Kepala Sekolah memberikan sarana dan prasarana sekolah dengan memanfaatkan teknologi informasi dan komunikasi untuk pembelajaran.

3. Guru

Sebaiknya guru lebih memfasilitasi pengembangan potensi peserta didik dengan menyediakan kegiatan pembelajaran selain di ruang kelas.

4. Dosen selaku civitas akademis perlu mengawal jalannya implementasi kurikulum 2013 supaya kekurangan dan permasalahan yang ditemukan pada kurikulum-kurikulum sebelumnya tidak teerulanng kembali 
serta mutu pendidikan Negara Indonesia menjadi lebih baik.

\section{DAFTAR RUJUKAN}

Arikunto Suharsimi,2003. Posedur Penelitian Suatu Pendekatan Praktek, Rineka Cipta, Yogyakarta.

Evanita, Eka Lusia. 2013. Analisis kompetensi Pedagogik dan Kesiapan Guru Sekolah Menengah Atas Dalam Mendukung Implementasi Kurikulum 2013. Skripsi Tidak Diterbitkan. Universitas Negeri Semarang

Hamalik O. 2008. Manajemen Pengembangan Kurikulum. Bandung: Remaja Rosdakarya.

Hasan H. 2013. Informasi Kurikulum 2013. Bandung: Universitas Pendidikan Indonesia.

Husain A, AH Dogar, M Azeem \& A Shakoor. 2011.Evaluation of Curriculum

Development Proces. International Journal of Humanities and Social Science 1 (14):263-271.

Iskandar H. 2013. Desain Induk Kurikulum 2013. Jakarta: Kementerian Pendidikan dan Kebudayaan.

Kementerian Pendidikan dan Kebudayaan. 2012. Bahan Uji Publik Kurikulum 2013. Jakarta: Kementerian Pendidikan dan Kebudayaan. . 2013a. Materi Pelatihan Guru Implementasi Kurikulum 2013 SMP/MTs Ilmu Pengetahuan Alam. Jakarta: Kementerian Pendidikan dan Kebudayaan. . 2013b. Pedoman Pelatihan Implementasi Kurikulum 2013. Jakarta: Kementerian Pendidikan dan Kebudayaan. 2013c. Pedoman Pemberian Bantuan Implementasi Kurikulum Tahun 2013. Jakarta: Kementerian Pendidikan dan Kebudayaan.

2013d. Pengembangan Kurikulum 2013. Jakarta: Kementerian Pendidikan dan Kebudayaan.

Mulyasa E. 2014. Standar Kompetensi dan Sertifikasi Guru. Bandung: Remaja Rosdakarya.

Nasution S. 2008. Asas-Asas Kurikulum. Edisi Kedua. Jakarta: Bumi Aksara.

Peraturan Menteri Pendidikan Nasional. 2007. Peraturan Menteri Pendidikan Nasional nomor 16 tahun 2007 tentang Standar Kualifikasi Akademik dan Kompetensi Guru. Jakarta: BSNP.

Peraturan Pemerintah Republik Indonesia. 2009. Peraturan Pemerintah Republik Indonesia nomor 19 tahun 2005 tentang : standar nasional pendidikan. Jakarta: Pemerintah Republik Indonesia. 